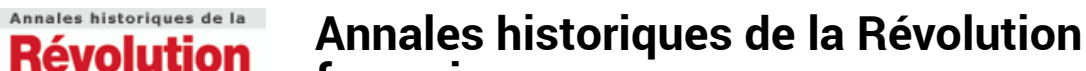

française française

328 | avril-juin 2002

La Révolution et le Droit

\section{La place de la partie lésée dans le procès pénal révolutionnaire}

Jacques Leroy

\section{OpenEdition}

1 Journals

Édition électronique

URL : https://journals.openedition.org/ahrf/617

DOI : 10.4000/ahrf.617

ISSN : 1952-403X

Éditeur :

Armand Colin, Société des études robespierristes

\section{Édition imprimée}

Date de publication : 1 juin 2002

Pagination : 105-119

ISSN : 0003-4436

\section{Référence électronique}

Jacques Leroy, «La place de la partie lésée dans le procès pénal révolutionnaire », Annales historiques de la Révolution française [En ligne], 328 | avril-juin 2002, mis en ligne le 20 avril 2004, consulté le 24 avril 2022. URL : http://journals.openedition.org/ahrf/617 ; DOI : https://doi.org/10.4000/ahrf.617

Ce document a été généré automatiquement le 24 avril 2022.

Tous droits réservés 


\title{
La place de la partie lésée dans le procès pénal révolutionnaire
}

\author{
Jacques Leroy
}

\section{RÉSUMÉS}

Quelles ont été, durant la Révolution, les prérogatives des victimes d'infractions dans le procès pénal? L'analyse de la législation alors applicable permet deux observations: d'abord, dès la Constituante, la victime peut devenir un accusateur. Les révolutionnaires redécouvrent les vertus de l'accusation privée qu'ils mettront dix ans à éliminer au profit de l'accusation publique. On peut remarquer que l'Ancien Régime était déjà parvenu au même résultat dans l'Ordonnance criminelle de 1670. Ensuite, la Convention inscrit clairement, et pour la première fois, en 1795 dans le code des délits et des peines les définitions des actions publique et civile, ce qui fixe définitivement l'objet de la demande des parties lésées dans le procès répressif. Quelles que soient les prérogatives procédurales dont elle dispose, la victime ne doit les utiliser qu'à fins réparatrices. À cet égard, l'Ordonnance de 1670 avait déjà fait le premier pas. L'œuvre législative postérieure à la Révolution confirmera la séparation des fonctions de poursuite et de réparation.

\section{The Place of the Injured Party in the Revolutionary System}

What were, during the Revolution, the rights of victims of crimes in the penal system? The analysis of the relevant legislation permits two observations. First, from the time of the Constituent Assembly, the victim could become an accuser. The revolutionaries rediscovered the virtues of private accusation, and it would take them 10 years to eliminate it in favor of public accusation. One may note that the Old Regime had already arrived at the same conclusion in the Criminal Ordinance of 1670 . Second, the Convention inscribes clearly for the first time the definitions of public and civil lawsu its in the 1795 Code of Penalties and Punishments, thereby definitively fixing the claims of injured parties in the repressive process. Whatever the 
procedural prerogatives at their disposal, victims could only use them for reparatory ends. In this respect, the 1670 Ordinance had already taken the first step. Legislation passed in the wake of the Revolution would confirm the separation of the functions of prosecution and restitution.

\section{INDEX}

Mots-clés : accusations publique et privée, actions publique et civile, constitution de partie civile, jury, dénonciation, plainte, souveraineté, ordonnance criminelle de 1670, code des délits et des peines 